\title{
У Mitä sairauspäivärahan enimmäisajan täytyttyä? Toimeentulon lähteet kahden vuoden seurannassa
}

Tutkittu tieto sairauspäivärahan enimmäisajan jälkeisestä toimeentulosta on puuttunut Suomessa. Tutkimme työkyvyttömyyseläkkeelle siirtymistä, ansiotyö- ja työttömyysjaksoja, ammatillista kuntoutusta sekä uusia sairauspäivärahakausia kahden vuoden seurannassa henkilöillä, joiden sairauspäivärahan enimmäisaika oli tullut täyteen 2012. Tarkastelimme myös, miten päivärahaa saaneiden tausta oli yhteydessä enimmäisajan jälkeisten työkyvyttömyyseläkehakemusten yleisyyteen.

Analysoimme kuvailevilla menetelmillä 70 prosentin edustavaa satunnaisotosta 18-60-vuotiaasta väestöstä hyödyntäen Eläketurvakeskuksen, Kelan ja Tilastokeskuksen rekisteritietoja. Tarkastelimme työkyvyttömyyseläkkeen hakemista ensisjjaisena toimeentulolähteenä. Muita toimeentulon lähteitä tarkastelimme taustatekijöillä vakioituina prevalensseina käyttäen logistista regressioanalyysiä. Testasimme taustatekijöiden yhteyttä enimmäisajan jälkeisen 12 kuukauden aikaisen eläkehakemuksen todennäköisyyteen khiin neliö -testeillä.

Enimmäisaikaa seuraavan vuoden aikana $68 \%$ siirtyi työkyvyttömyyseläkkeelle, $14 \%$ ei hakenut työkyvyttömyyseläkettä ja 18 \%:lle ei myönnetty työkyvyttömyyseäkettä. Taustatekijöistä muu kuin toimihenkilöasema ja ansiotyön puuttuminen työkyvyttömyyden alkaessa selittivät vahvimmin työkyvyttömyyseläkkeen hakemista. Eläkettä hakematta jättäneet olivat usein ansiotyössä ensimmäisen seurantavuoden aikana $(69 \%)$. Hylkäävän eläkepäätöksen saaneista valtaosa sai työttömyysetuutta ensimmäisen $(80 \%)$ tai toisen $(72 \%)$ seurantavuoden aikana. Vuoden työkykyisyysajan jälkeen uudet sairauspäivärahakaudet olivat yleisiä.

Sairauspäivärahan enimmäisajan täyttyminen merkitsee valtaosalla täyden työkyvyn menettämistä seuraaviksi vuosiksi riippumatta siitä, johtaako sairausjakso suoraan työkyvyttömyyseläkkeeseen. Pitkään sairauspäivärahalla olevien tilannetta pitäisi tukea tehokkaammin sairauspäivärahajaksojen aikana ja enimmäisajan lähestyessä. Erityisesti tämä koskee ansiotyön ulkopuolella olevia, joilta puuttuvat työterveyshuollon palvelut ja sairausvakuutuslain mukaiset, päivärahakauden sisäiset seurantapisteet.

ASIASANAT: sairauspäiväraha, enimmäisaika, työkyvyttömyyseläke, toimeentulon lähteet

RIKU PERHONIEMI, JENNI BLOMGREN, MIKKO LAAKSONEN 


\section{YDINASIAT}

- Tutkimuksessa muodostettiin ensi kertaa yleiskäsitys toimeentulon lähteistä sairauspäivärahan enimmäisajan jälkeen.

- Enimmäisajan täyttyminen merkitsi valtaosalla täyden työkyvyn menettämistä, mikä näkyi työkyvyttömyyseläkkeelle siirtymisen ja vuoden työkykyisyysajan jälkeisten uusien sairausjaksojen yleisyytenä sekä ansiotyön vähenemisenä seurannan aikana.

- Erityisesti työttömillä työkyvyttömyyden ehkäisy vaatisi ennakointia mutta myös oikeita menettelyjä päivärahajakson pitkittyessä.

\section{JOHDANTO}

Työkyvyttömyydestä aiheutuu sekä yksilöille että kansantalouksille huomattavia kustannuksia. Työkyvyttömyyden aiheuttamat julkiset menot ovat suuria erityisesti Pohjoismaissa, joissa ne ovat jopa neljä prosenttia bruttokansantuotteesta (1). Suomessa työurien pidentäminen ja riittävän työllisyysasteen saavuttaminen ovat väestön ikääntyessä ylipäänsä haasteita julkiselle taloudelle. Työkyvyttömyyden ehkäiseminen on keskeisen tärkeää, jotta näihin haasteisiin pystytään vastaamaan.

Huomattava osa työkyvyttömyyden kokonaiskustannuksista aiheutuu pysyvästä työkyvyttömyydestä (2). Aiemman tutkimuksen perusteella työkyvyttömyyseläkkeelle siirtymisen riskiä lisäävät huomattavasti pitkät sairauspoissaolot (3-5). Toisaalta pitkäkään sairauspoissaolo ei aina johda työkyvyttömyyseläkkeelle. On tärkeää ymmärtää yhtäältä tekijöitä, jotka ennustavat sairauspoissaolon muuttumista pysyväksi työkyvyttömyydeksi ja toisaalta sairauspoissaolojen jälkeisiä muita toimeentulopolkuja.

\section{TYÖKYYYTTÖMYYDEN RISKIIN VAIKUTTAVAT TEKIJÄT JA TYÖHÖN PALAAMINEN SAIRAUDEN JäLKEEN}

Kotimaisten ja kansainvälisten tutkimusten mukaan sairauspoissaoloriskiä nostavat muun muassa korkea ikä ja matala ammattiasema (6-11). Korkeampi ikä, alempi sosioekonominen asema ja vähäisempi työura lisäävät myös työkyvyttömyyseläkeriskiä (12-16).

Toisaalta aiempi tutkimus on tarkastellut sairauden ja työkyvyttömyyden jälkeisiä polkuja, kuten työhön paluuta tai pysyvälle työkyvyttömyysetuudelle siirtymistä. Näiden tutkimusten mukaan työhön paluun todennäköisyyttä sairauden tai kuntoutuksen jälkeen heikentävät yleisesti alempi ammattiasema, alempi koulutustaso, korkeampi ikä ja sairausjakson pidentyminen (17-21). Alempi sosioekonominen asema ja korkeampi ikä lisäävät myös todennäköisyyttä sairausjakson aikaiselta etuudelta työkyvyttömyyseläkkeelle siirtymiseen (13, 22-24). Sukupuolierot sairausjakson jälkeisessä työhön paluussa tai eläkkeen todennäköisyydessä näyttävät vaihtelevan tutkimusten, maiden ja sairausryhmien välillä $(17,19,23)$. Pedersen kollegoineen (24) tutki Tanskassa siirtymiä sairausjakson aikaisen työkyvyttömyysetuuden, työn, työttömyyden ja työkyvyttömyyseläkkeen välillä neljän vuoden aikana. Sairausjaksolta työhön siirtyi seurannan aikana vähintään kerran noin 80 prosenttia tutkittavista, kun työttömäksi työnhakijaksi puolestaan sairausjaksolta siirtyviä oli noin neljännes ja työkyvyttömyyseläkkeelle siirtyviä hieman alle kymmenesosa. Työhön siirtyvät olivat muita useammin miehiä, nuoria aikuisia ja ehjän työuran omaavia henkilöitä. Työttömäksi sairausjaksolta siirtyvät henkilöt sen sijaan olivat muita useammin nuoria, olleet työttömänä jo aiemmin sekä olivat muita harvemmin yrittäjiä. Työkyvyttömyyseläkkeelle siirtymisen todennäköisyyttä puolestaan nosti korkeampi ikä ja suurempi määrä aiempia sairauspoissaoloja. Myös sairauspoissaolon taustalla oleva sairaus voi vaikuttaa sairausjakson jälkeisiin toimeentulopolkuihin. Aiemman tutkimuksen mukaan mielenterveysperusteinen sairauspoissaolo voi lisätä työkyvyttömyyseläkeriskiä muita sairausjakson diagnooseja vahvemmin $(4,13)$ ja vähentää tai hidastaa sairausjakson jälkeistä työhön paluuta (24,25).

Kertyneestä tutkimustiedosta huolimatta pitkien sairauspoissaolojen seurauksia ei ole edelleenkään tutkittu riittävästi. Usein on keskitytty sairausjaksoa seuraavan työhön paluun tai työkyvyttömyyseläkkeen todennäköisyyksiä nostaviin tekijöihin, mutta muista sairauden jälkeisistä toimeentulon muodoista ei juuri ole tutkimustietoa. Toinen tietotarve koskee toimeentulon lähteitä silloin, kun sairauspoissaoloetuuden enimmäismäärä tulee täyteen. Ne henkilöt, jotka ovat käyttäneet enimmäismäärän sairauspoissaoloa korvaava etuutta mutta eivät siirry työkyvyttömyyseläkkeeseen, saattavat työkykyisyyden ollessa epäselvää joutua muun muassa erilaisiin 
etuuskierteisiin (26-28). Tämä tutkimustarve nousee aiemman kansainvälisen tutkimuksen ohella kansallisesta tietotarpeesta. Suomessa työkyvyttömyyden aikaista toimeentuloa turvaa ensisijaisesti sairauspäiväraha. Tutkittua tietoa ei ole siitä, kuinka moni hakee työkyvyttömyyseläkettä tai siirtyy työkyvyttömyyseläkkeelle sairauspäivärahan enimmäisajan jälkeen, tai mistä enimmäisajan käyttäneiden toimeentulo vaihtoehtoisesti muodostuu. Samoin puuttuu tieto siitä, miten demografinen, sosioekonominen ja sairausjaksoon liittyvä tausta on yhteydessä näihin toimeentulon polkuihin sairauspäivärahan enimmäisajan jälkeen.

Näiden kysymysten selvittäminen on yksi tapa tarkastella suomalaisen työkyvyttömyyteen liittyvän tukijärjestelmän kokonaisuutta, joka on luotu ehkäisemään työkyvyttömyyttä ja varmistamaan toimeentuloa työkyvyttömyyden aikana. Työkyvyttömyyteen ja työhön paluuseen liittyvien prosessien seuraaminen on korostuneen tärkeää juuri nyt, kun pitkät sairauspoissaolot ja työkyvyttömyyseläkkeet ovat uudelleen yleistyneet pitkäaikaisen vähenemisen jälkeen (29, 30). Toisaalta työkyvyttömyysetuudet eivät toimi tyhiössä vaan ovat osa sosiaaliturva- ja palvelujärjestelmän kokonaisuutta. Erityisesti eri elämäntilanteiden siirtymävaiheissa ja osatyökykyisyyteen liittyvissä tilanteissa ei ole aina selkeää, mikä etuus turvaa asiakkaan toimeentuloa. Aiemmat tutkimukset ovat tässä yhteydessä korostaneet erityisesti työttömyys- ja työkyvyttömyysetuuksien linkittymistä ja vuorottelua, joka koskettaa etuusjärjestelmän väliinputoajia (31,32).

\section{SAIRAUSPÄIVÄRAHAETUUDEN ENIMMÄISAIKA JA TYÖKYVYTTÖMYYSELÄKE}

Suomen sairauspäivärahajärjestelmä on rakennettu varmistamaan toimeentulo työkyvyn tilapäisen heikentymisen aikana. Jos henkilön työkyky on alentunut sairauden tai vamman takia, voidaan hänelle maksaa sairauspäivärahaa yleensä sairastumispäivän ja yhdeksän arkipäivän pituisen omavastuuajan jälkeen. Sairauspäivärahaa voidaan saman sairauden perusteella pääsääntöisesti maksaa enintään 300 arkipäivältä eli noin vuoden ajalta. Tämä enimmäisaika voi kertyä yhtäjaksoisesti tai useista lyhyistä jaksoista enintään kahden vuoden aikana. Lisäksi vuodesta 2011 on voitu tarvittaessa maksaa sairauspäivärahaa
50 lisäpäivältä, jos henkilö on palannut vähintään kuukauden ajaksi työhön 300 päivän täytyttyä (33). Vuonna 2019 alkaneita yksittäisiä sairauspäivärahakausia (sisältäen lisäpäiväkaudet) oli 308530 (34). Tietoa yhden kalenterivuoden aikana enimmäisajan täyttäneiden henkilöiden lukumäärästä ei Kelan tilastoista kuitenkaan löydy.

Sairauspäivärahakauteen on rakennettu sairausvakuutuslain (33) mukaisia seurantapisteitä, joiden tarkoitus on ehkäistä sairauden paheneminen ja vahvistaa ensisijaisia kuntoutuksen ja työhön paluun vaihtoehtoja $(33,35)$. Viimeistään 90 sairauspäivärahapäivän kohdalla jäljellä olevaa työkykyä ja mahdollisuuksia jatkaa työssä arvioidaan työterveyshuollon, työntekijän ja työnantajan yhteistyönä. Jos työkyvyttömyys kuitenkin jatkuu 300 päivän enimmäisajan täyttymisen jälkeen, voidaan henkilölle myöntää työkyvyttömyyseläke. Kela tiedottaa työkyvyttömyyseläkkeen hakemisesta ja kuntoutusmahdollisuuksista siinä vaiheessa, kun sairauspäivärahaa on maksettu 150 päivän ajan.

Työkyvyttömyyseläkkeen myöntäminen edellyttää sairauden tai vamman aiheuttamaa, vähintään vuoden yhtäjaksoista, diagnosoitua kyvyttömyyttä työhön. Useimmiten tämä ehto täyttyy sairauspäivärahan enimmäisajan kautta. Toisin kuin sairauspäivärahan kohdalla, eläkeratkaisussa käytetään pääosin yleistä työkyvyttömyyden määritelmää, eli henkilön on oltava kyvytön kaikkeen sellaiseen työhön, jota hänen voidaan kohtuudella edellyttää tekevän (esim. Työntekijän eläkelaki [36]). Työeläkehakemusten kohdalla voidaan myöntää osatyökyvyttömyyseläke, kun työkyvyn arvioidaan alentuneen $40-60$ prosentin verran, muttei täyteen eläkkeeseen oikeuttavasti (työkyvyn alenema vähintään 60 prosenttia).

Työkyvyttömyyseläkkeen hakeminen pitkään sairauspäivärahalla olleelle on usein luontaisin vaihtoehto. Näin on erityisesti silloin, kun henkilö kokee itsensä edelleen työkyvyttömäksi eikä mahdollinen hoito, kuntoutus tai työn uudelleen organisointi ole muuttanut tilannetta. Toisaalta henkilö saattaa hakea osatyökyvyttömyyseläkettä, jos osa työkyvystä on palautunut sairauspoissaolon aikana ja osittainen työssä jatkaminen onnistuu. Kansaneläkejärjestelmässä vaihtoehtona on vain täysi työkyvyttömyyseläke. Työttömillä saattaa puolestaan olla yleisesti ottaen ansiotyötä tekeviä suurempi kannuste hakea työky- 
vyttömyyseläkettä sairauspäivärahan enimmäisajan jälkeen, koska eläke tarjoaa usein työttömyysetuutta varmemman ratkaisun toimeentuloon (37).

Osa työkyvyttömyyseläkkeen hakijoista saa eläkelaitokselta hylkäävän päätöksen. Uuteen, täyttä työkyvyttömyyseläkettä koskevaan hakemukseen hylkäävän päätöksen saaneita työikäisiä henkilöitä on vuosittain karkeasti arvioiden noin 10000 (27,30,34). Heidän osaltaan tiedetään, että ansiotyö on hylkäävän päätöksen jälkeisinä vuosina harvinaista, työkyvyttömyyseläkeprosessin jatkuminen ja työttömyysetuuden saaminen sen sijaan tyypillistä $(27,32,38)$.

On selvää, etteivät kaikki sairauspäivärahan enimmäisajan päätyttyä hae työkyvyttömyyseläkettä. Henkilö voi palata aiempaan työhönsä tai hakea uutta työtä, jos hänen toimintakykynsä on parantunut. Samoin ammatillinen tai lääkinnällinen kuntoutus voi jatkua sairauspäivärahan enimmäisajan täyttymisen jälkeen. Samoin uuden sairauden perusteella maksetut sairauspäivärahakaudet ovat mahdollisia. Sairauspäivärahaa ei voida kuitenkaan maksaa uudelleen sellaisen sairauden perusteella, joka on ollut enimmäisaikana maksetun päivärahan perusteena, kuin vasta vuoden kestäneen yhtäjaksoisen työkykyisyysajan jälkeen (33). Enimmäisajan jälkeen saatetaan toisaalta olla työttömyysetuudella, vaikka se ei olekaan tarkoituksenmukaisin etuus, jos työkyky ei ole kohentunut. Tämä koskee luonnollisesti erityisesti henkilöitä, jotka ovat olleet ansiotyön ulkopuolella jo työkyvyttömyyden alkaessa.

\section{TUTKIMUKSEN TAVOITTEET JA TUTKIMUSKYSYMYKSET}

Tämän tutkimuksen tavoitteena oli tarkastella työkyvyttömyyseläkkeen hakemista, työkyvyttömyyseläkkeelle siirtymistä, ansiotyöhön osallistumista, työttömyysetuuden saamista, ammatillista kuntoutusta sekä uusia sairauspäivärahakausia kahden vuoden seurannassa sairauspäivärahan enimmäisajan täyttymisen jälkeen. Koska sairauspäivärahan enimmäisajan täyttymisen jälkeen myönnetty työkyvyttömyyseläke varmistaa useimpien toimeentulon, tarkastelimme työkyvyttömyyseläkkeelle siirtymistä ensisijaisena tulomuotona. Tarkastelimme demografisia, sosioekonomisia ja sairausjaksoon liittyviä taustatekijöitä yhtäältä työkyvyttömyyseläkkeen hakemisen taustatekijöinä sekä toisaalta vakioitavina tekijöinä muiden toimentulon lähteiden taustalla.
Tutkimuskysymyksemme ovat:

1. Kuinka yleistä on työkyvyttömyyseläkkeelle siirtyminen, työkyvyttömyyseläkkeen hakeminen mutta hylkäävän päätöksen saaminen sekä eläkettä hakematta jättäminen sairauspäivärahan enimmäisajan täytyttyä?

2. Miten taustatekijät ovat yhteydessä yhtäältä hylkäävän työkyvyttömyyseläkepäätöksen saamisen ja toisaalta hakematta jättämisen todennäköisyyksiin sairauspäivärahan enimmäisajan täytyttyä?

3. Kuinka yleisiä ovat ansiotyö, työttömyysetuus, ammatillinen kuntoutus ja uudet sairauspäivärahakaudet niillä henkilöillä, jotka saivat hylkäävän työkyvyttömyyseläkepäätöksen ja henkilöillä, jotka eivät hakeneet työkyvyttömyyseläkettä sairauspäivärahan enimmäisajan täytyttyä?

\section{AINEISTO JA MENETELMÄT}

\section{AINEISTO}

Tutkimuksessa käytettiin rekisteritietoa Eläketurvakeskuksen ja Kelan eläkeratkaisuista, sairauspäiväraha-, työttömyysetuus- ja ansiotyöpäiväjaksoista, ammatilliseen kuntoutukseen tarkoitetuista kuntoutusrahajaksoista, Kelan maksamista ammatillisista kuntoutuksista sekä Kelan ja Tilastokeskuksen tietoja väestön demografisista ja sosioekonomisista taustatekijöistä. Tutkimuksen kohdejoukoksi poimittiin rekistereistä 70 prosentin edustava satunnaisotos 18-60-vuotiaista Suomen väestöön vuoden 2011 lopussa kuuluneista henkilöistä. Yläikäraja määriteltiin, jotta tutkittavat eivät saavuttaisi alinta vanhuuseläkeikää (63 vuotta) tutkimuksen kahden vuoden seuranta-aikana. Kohdejoukko rajattiin edelleen henkilöiksi, joille maksettujen sairauspäivärahapäivien enimmäismäärä tuli täyteen kalenterivuoden 2012 aikana. Käytännössä tarkastelimme niitä, joiden sairauspäivärahapäivien summaksi tuli 270-299 päivää edellisen kahden vuoden aikana, koska sairauspäivärahaa maksetaan enintään sen kuukauden loppuun, jota seuraavan kuukauden aikana 300 päivärahapäivää tulisi täyteen. Tutkimusaineisto muodostui 13081 henkilöstä. 


\section{SEURANTA-AIKA JA TARKASTELTAVAT TOIMEENTULON LÄHTEET}

Seurannan lähtökohdaksi otettiin sairauspäivärahan enimmäisajan täyttymispäivä vuonna 2012. Koska myönnetty työkyvyttömyyseläke varmistaa useimpien toimeentulon, eriteltiin tutkittavista ensin ne, jotka siirtyivät sairauspäivärahalta työkyvyttömyyseläkkeelle enimmäisajan täyttymistä seuraavan vuoden aikana. Emme siis huomioineet tämän ryhmän muita toimeentulon muotoja, vaikka osa tässä ryhmässä olleista oli ennen työkyvyttömyyseläkkeen alkamista saattanut olla jonkin aikaa myös muilla etuuksilla tai ansiotyössä. Tämän jälkeen toimeentulon muotojen tarkempi seuranta kohdistettiin niihin henkilöihin, jotka joko 1) eivät hakeneet työkyvyttömyyseläkettä tai 2) hakivat työkyvyttömyyseläkettä, mutta eläkettä ei myönnetty.

Ansiotyön, työttömyyden, ammatillisen kuntoutuksen, sairauspäivärahan lisäpäivien ja uusien sairauspäivärahajaksojen yleisyyttä seurattiin erikseen ensimmäisen seurantavuoden (kuukaudet 1-12 enimmäisajan täyttymisen jälkeen) ja toisen seurantavuoden aikana (kuukaudet 13-24). Seurantavuosia tarkasteltiin erikseen, koska vuoden työkykyisyysajan jälkeen henkilöllä on jälleen oikeus saada sairauspäivärahaa myös sellaisen sairauden perusteella, jolla päivärahaa oli enimmäisaikana maksettu. Toisen seurantavuoden osalta otettiin jälleen seurantaan myös työkyvyttömyyseläkkeelle siirtyminen.

\section{TARKASTELTAVAT TAUSTATEKIJÄT}

Tarkastelimme useita sellaisia taustatekijöitä, jotka voivat vaikuttaa sairauspäivärahan enimmäisajan jälkeiseen työkyvyttömyyseläkkeen hakemiseen ja eläkkeelle siirtymiseen. Demografisina taustatekijöinä tarkasteltiin sukupuolta ja ikää. Sosioekonomisina taustatekijöinä tarkastelimme Tilastokeskuksen määrittelemää, ammattiasemaan perustuvaa sosioekonomista asemaa (39) ja ansiotyötä työkyvyttömyyden alkaessa. Myös pääasiallinen diagnoosi (ICD-10 -luokitus), joka oli ollut päivärahakertymän viimeisen yksittäisen sairauspäivärahajakson syynä, huomioitiin taustatekijänä. Näillä tekijöillä on ollut yhteys sairauden jälkeisiin toimeentulon lähteisiin aiemmissa tutkimuksissa (4,13, 17-25). Diagnoosit luokiteltiin mielenterveyden häiriöihin (ICD-10 F00-F99), tuki- ja liikuntaelinten (TULE-) sairauksiin (ICD-
10 M00-M99) ja muihin sairauksiin. Ikä luokiteltiin neljään ryhmään: 18-29, 30-39, 40-49 ja 50-60 vuotta. Ansiojaksoista tarkasteltiin, oliko henkilö ollut ansiotyössä työkyvyttömyyden alkaessa.

Muita taustatekijöitä olivat viimeisin ansiotyön sektori ennen työkyvyttömyyttä ja sairauspäivärahakertymän yhtenäisyys. Työsektori voi Suomessa olla merkittävä tekijä sairausjakson jälkeiselle työkyvyttömyyseläkkeen hakemiselle ja eläkkeelle siirtymiselle, sillä julkisella sektorilla työkyvyttömyyseläkkeen kriteerit ovat muita sektoreita lievemmät - eläkkeistä päätettäessä sovelletaan ammatillista, ei yleistä työkyvyttömyysmääritelmää (40). Viimeisimmäksi työsektoriksi merkittiin yksityinen tai julkinen käyttäen tietoa viimeisimmästä ansiotyökaudesta. Sairauspäivärahakauden yhtenäisyys puolestaan kertoo, että henkilö on ollut yhtämittaisesti työkyvytön 300 päivän ajan. Koska se puolestaan kertoo monella työkyvyttömyyden vakavuudesta, saattaa yhtenäinen sairausjakso lisätä työkyvyttömyyseläkkeen hakemisen todennäköisyyttä. Päivärahakertymän epäyhtenäisyys puolestaan tarkoittaa, että enimmäisaika on täyttynyt erillisistä jaksoista. Jaksojen väleissä on voinut olla jaksoja, jolloin henkilö on ollut työkykyinen, kokeillut työn tekoa tai toimeentulo on rakentunut muista etuuksista. Enimmäismäärän täyttänyt sairauspäivärahajakso merkittiin yhtenäiseksi, jos enimmäismääräkertymä täyttyi yhdestä jaksosta tai erillisten jaksojen välissä ei ollut välipäiviä.

Sukupuolen mukaan tutkittavat jakautuivat tasaisesti (Taulukko 1). Yli puolet tutkittavista oli täyttänyt 50 vuotta. Samoin tutkittavissa painottui sosioekonominen asema "muu", sisältäen pitkäaikaistyöttömiä, opiskelijoita ja henkilöitä ilman selkeää sosioekonomista asemaa. Runsas kaksi kolmannesta oli ollut ansiotyössä työkyvyttömyyden alkaessa. Yli kaksi kolmesta oli viimeisimmässä työssään työskennellyt yksityisellä sektorilla. Noin puolella enimmäisaika oli täyttynyt yhdestä jaksosta tai yhtenäisestä sairausjaksojen kokonaisuudesta. Noin kolmanneksella sairauspäivärahakauden viimeisin diagnoosi oli mielenterveyden häiriö ja reilulla kolmanneksella tuki- ja liikuntaelinten sairaus. 
Taulukko 1. Taustamuuttujien jakaumat (\%) sekä työkyvyttömyyseläkkeen hakeminen ja työkyvyttömyyseläkkeelle siirtyminen sairauspäivärahan enimmäisajan vuonna 2012 saavuttaneilla.

Kaikki sairauspäivärahan enimmäisajan saavuttaneet $(\%)$

Sukupuoli

Mies 49

Nainen

51

Ikäryhmä

18-29

30-39

40-49

50-60

Sosioekonominen asema

Ylempi toimihenkilö 6

Alempi toimihenkilö 23

$\begin{array}{lr}\text { Työntekijä } & 29\end{array}$

Yrittäjä 9

Muu 33

Ansiotyössä työkyvyttömyyden alkaessa

Ei

Kyllä

Viimeisin työsektori

Yksityinen

Julkinen

Puuttuva tieto

Sairauspäivärahakauden yhtenäisyys

Yhtenäinen

Epäyhtenäinen

Sairausjakson pääasiallinen diagnoosi

Mielenterveyden ja käyttäytymisen häiriö

Tuki- ja liikuntaelinten sairaus

Muu diagnoosi

Työkyvyttömyyseläkkeelle siirtyminen / eläkkeen hakeminen enimmäisajan jälkeen

Siirtyi työkyvyttömyyseläkkeelle

Haki työkyvyttömyyseläkettä ja hakemus hylättiin

Ei hakenut työkyvyttömyyseläkettä

\section{TILASTOLLISET MENETELMÄT}

Taustatekijöiden yhteyttä hylkäävän työkyvyttömyyseläkepäätöksen saamiseen ja eläkettä hakematta jättämiseen (tutkimuskysymys 2) testattiin multinomiaalisella logistisella regressioanalyysilla Stata 14-ohjelmistolla. Toimeentulon lähteiden yleisyydet esitetään vakioimattomina ja taustatekijöillä vakioituina osuuksina yhtäältä hylkäävän työkyvyttömyyseläkepäätöksen saaneille ja toisaalta henkilöille, jotka eivät hakeneet työkyvyttömyyseläkettä (tutkimuskysymys 3). Erot taustatekijöiden jakaumissa näiden ryhmien välillä vakioitiin binäärisillä logistisilla regressioanalyyseillä. Näissä analyyseissä tuotettiin vakiointiin perustuvat estimoidut prevalenssit toimeentulon lähteille (margins-komento). 


\section{TULOKSET}

\section{TYÖKYVYTTÖMYYSELÄKEHAKEMUKSET JA ELÄKKEELLE SIIRTYMINEN SAIRAUSPÄIVÄRAHAN ENIMMÄISAJAN TÄYTYTTYÄ}

Sairauspäivärahan enimmäisajan täyttäneistä $68 \%$ siirtyi työkyvyttömyyseläkkeelle seuraavan vuoden (12 kuukautta) aikana. $18 \%$ enimmäisajan täyttäneistä haki työkyvyttömyyseläkettä mutta sitä ei myönnetty. $14 \%$ puolestaan ei hakenut työkyvyttömyyseläkettä sairauspäivärahan enimmäisajan täyttymistä seuraavan vuoden aikana (Taulukko 1).

\section{TAUSTATEKIJÖIDEN YHTEYS TYÖKYVYTTÖMYYSELÄKKEEN HYLKÄÄVÄN TYÖKYYYTTÖMYYSELÄKEPÄÄTÖKSEN SAAMISEEN JA ELÄKETTÄ HAKEMATTA JÄTTÄMISEEN}

Taulukossa 2 on esitetty multinomiaalisen logistisen regressiomallin tulokset. Referenssiryhmänä toimivat työkyvyttömyyseläkkeelle siirtyneet, joihin verrattiin yhtäältä hylkäävän päätöksen saaneita ja toisaalta eläkettä hakematta jättäneitä.

Naiset, 30-49-vuotiaat, sosioekonomiselta asemaltaan ryhmässä "muu" olleet (sisältäen muun muassa pitkäaikaistyöttömät), ilman ansiotyötä työkyvyttömyyden alkaessa olleet, yksityisellä sektorilla työskennelleet, epäyhtenäisellä sairauspäivärahajaksolla olleet ja TULE-sairauden perusteella sairauspäivärahalla olleet saivat muita todennäköisemmin hylkäävän työkyvyttömyyseläkepäätöksen. Vähintään 50- vuotiaat puolestaan saivat nuorimpia hakijoita harvemmin hylkäävän päätöksen.

Nuoremmat ikäryhmät, ylemmät toimihenkilöt, ansiotyössä työkyvyttömyyden alkaessa olleet, edellisessä ansiotyössään julkisella sektorilla olleet ja epäyhtenäisellä sairauspäivärahajaksolla olleet jättivät hakematta työkyvyttömyyseläkettä muita ryhmiä todennäköisemmin. Samoin TULE-sairauden tai muun sairauden perusteella sairauspäivärahalla olleet jättivät työkyvyttömyyseläkkeen hakematta mielenterveyden häiriöstä kärsiviä useammin.

Taulukon 2 tuloksista voidaan myös nähdä, että työkyvyttömyyseläkkeelle siirtyivät (referenssiryhmä) muita useammin vähintään 50-vuotiaat, yhtenäisellä sairauspäivärahajaksolla olleet ja mielenterveyden häiriön perusteella sairauspäivärahalla olleet henkilöt. Näiden taustatekijöiden osalta nimittäin sekä hylkäävän päätöksen saa- neet että eläkettä hakematta jättäneet erosivat eläkkeelle siirtyneistä johdonmukaisella tavalla.

\section{TYÖKYYYTTÖMYYSELÄKKEELLE SIIRTYMISELLE VAIHTOEHTOISET TOIMEENTULON LÄHTEET}

Kuviossa 1 on esitetty tarkasteltavien toimeentulon lähteiden yleisyys sairauspäivärahan enimmäisajan täyttymistä seuraavan vuoden aikana henkilöillä, jotka saivat hylkäävän eläkepäätöksen ja henkilöillä, jotka eivät hakeneet työkyvyttömyyseläkettä. Kuviossa osuudet on esitetty sekä vakioimattomina että vakioituina, jolloin kahden tarkasteltavan ryhmän väliset erot taustatekijöiden jakaumissa on otettu huomioon. Eri toimeentulomuotojen osuudet eivät summaudu 100 prosenttiin, koska seurannan aikana tutkittavilla on voinut olla useita toimeentulon lähteitä.

Vaikka taustatekijöiden vakiointi loivensi kahden ryhmän välisiä eroja, olivat erot toimeentulon lähteiden yleisyydessä selkeät. Keskitymme tässä taustatekijöillä vakioituihin osuuksiin. Ensimmäisen seurantavuoden aikana henkilöt, jotka eivät hakeneet työkyvyttömyyseläkettä, olivat usein $(69 \%)$ ansiotyössä, kun taas hylkäävän työkyvyttömyyseläkepäätöksen saaneilla ansiotyö oli selvästi harvinaisempaa (51\%). Vastaavasti työttömyysetuus oli selvästi yleisempää hylkäävän työkyvyttömyyseläkepäätöksen saaneilla $(80 \%)$ verrattuna eläkettä hakematta jättäneisiin $(36 \%)$, samoin ammatillinen kuntoutus ( $22 \%$ vs. $12 \%$ ). Sairauspäivärahan lisäpäivät ( $2 \%$ vs. $3 \%$ ) ja uuden sairauden perusteella alkaneet sairauspäiväjaksot (4\% vs. $6 \%$ ) olivat harvinaisia molemmilla ryhmillä.

Kuviossa 2 on vastaavasti esitetty tarkasteltavien toimeentulon lähteiden yleisyys toisen seurantavuoden aikana. Henkilöt, jotka eivät hakeneet työkyvyttömyyseläkettä olivat ensimmäistä seurantavuotta harvemmin ansiotyössä $(57 \%)$, mutta edelleen selvästi hylkäävän eläkepäätöksen saaneita (46\%) useammin. Työttömyysetuus oli edelleen toisena seurantavuotena tyypillistä hylkäävän työkyvyttömyyseläkepäätöksen saaneille (72\%), kun työkyvyttömyyseläkettä hakematta jättäneillä sen yleisyys pysyi runsaassa kolmanneksessa $(38 \%)$. Ammatillisen kuntoutuksen yleisyys pysyi edelleen yleisempänä hylkäävän eläkepäätöksen saaneilla ( $21 \%$ ), ja väheni hieman ensimmäisestä seurantavuodesta eläkettä 
Taulukko 2. Multinomiaalinen logistinen regressioanalyysi ( $N=13$ 081). Referenssiryhmänä ryhmä 1 (siirtynyt työkyvyttömyyseläkkeelle, $\mathrm{N}=8837$ ). OR (odds ratio) = vetosuhde. Kaikki taustatekijät vakioitu samassa mallissa.

\begin{tabular}{|c|c|c|c|c|}
\hline & \multicolumn{2}{|c|}{$\begin{array}{l}\text { Ryhmä } 2 \text { vs. ryhmä } 1: \\
\text { Haki työkyvyttömyyseläkettä } \\
\text { ja hakemus hylättiin }\end{array}$} & \multicolumn{2}{|c|}{$\begin{array}{l}\text { Ryhmä } 3 \text { vs. ryhmä 1: } \\
\text { Ei hakenut työkyvyttömyys- } \\
\text { eläkettä }\end{array}$} \\
\hline & OR & $95 \% \mathrm{CI}$ & OR & $95 \% \mathrm{CI}$ \\
\hline \multicolumn{5}{|l|}{ Sukupuoli } \\
\hline Mies & 1,00 & & 1,00 & \\
\hline Nainen & $1,22 * * *$ & $1,11-1,35$ & 1,11 & $1,00-1,25$ \\
\hline \multicolumn{5}{|l|}{ Ikäryhmä } \\
\hline $18-29$ & 1,00 & & 1,00 & \\
\hline $30-39$ & $1,58 * * *$ & $1,30-1,93$ & 0,82 & $0,66-1,03$ \\
\hline $40-49$ & $1,37 * *$ & $1,14-1,65$ & $0,65 * * *$ & $0,53-0,80$ \\
\hline $50-60$ & $0,64 * * *$ & $0,53-0,77$ & $0,42 * * *$ & $0,35-0,51$ \\
\hline \multicolumn{5}{|l|}{ Sosioekonominen asema } \\
\hline Ylempi toimihenkilö & 1,00 & & 1,00 & \\
\hline Alempi toimihenkilö & 1,04 & $0,82-1,32$ & $0,80 *$ & $0,66-0,99$ \\
\hline Työntekijä & 1,06 & $0,84-1,34$ & $0,68 * * *$ & $0,55-0,84$ \\
\hline Yrittäjä & 1,10 & $0,84-1,45$ & $0,69 * *$ & $0,54-0,89$ \\
\hline Muu & $1,36^{*}$ & $1,08-1,72$ & $0,51 * * *$ & $0,41-0,63$ \\
\hline \multicolumn{5}{|l|}{ Ansiotyössä työkyvyttömyyden alkaessa } \\
\hline $\mathrm{Ei}$ & 1,00 & & 1,00 & \\
\hline Kyllä & $0,68 * * *$ & $0,61-0,76$ & $1,52 * * *$ & $1,31-1,76$ \\
\hline \multicolumn{5}{|l|}{ Viimeisin työsektori } \\
\hline Yksityinen & 1,00 & & 1,00 & \\
\hline Julkinen & $0,71 * * *$ & $0,63-0,80$ & $1,16^{*}$ & $1,03-1,31$ \\
\hline Puuttuva tieto & $0,70^{*}$ & $0,53-0,92$ & 1,05 & $0,74-1,50$ \\
\hline \multicolumn{5}{|l|}{ Sairauspäivärahakauden yhtenäisyys } \\
\hline Yhtenäinen & 1,00 & & 1,00 & \\
\hline Epäyhtenäinen & $1,45 * * *$ & $1,32-1,59$ & $1,52 * * *$ & $1,37-1,69$ \\
\hline \multicolumn{5}{|l|}{ Sairausjakson pääasiallinen diagnoosi } \\
\hline $\begin{array}{l}\text { Mielenterveyden ja käyttäytymisen } \\
\text { häiriö }\end{array}$ & 1,00 & & 1,00 & \\
\hline Tuki- ja liikuntaelinten sairaus & $1,88 * * *$ & $1,67-2,12$ & $1,63 * * *$ & $1,42-1,88$ \\
\hline Muu diagnoosi & 1,06 & $0,93-1,20$ & $1,48^{* * *}$ & $1,29-1,69$ \\
\hline
\end{tabular}

$* * * \mathrm{p}<.001 ; * * \mathrm{p}<.01 ; * \mathrm{p}<.05$.

hakematta jättäneiden ryhmässä ( $8 \%$ ). Ansio- ja työttömyyskausien vähentyessä ja vuoden pituisen työkykyisyysajan päätyttyä yleistyivät vastaavasti uudet sairauspäivärahakaudet. Ne olivat erityisen yleisiä hylkäävän työkyvyttömyyseläkepäätöksen saaneilla $(30 \%)$. Neljä prosenttia molemmista ryhmistä siirtyi työkyvyttömyyseläkkeelle toisena seurantavuotena. 
Kuvio 1.

Toimeen-

tulon lähteet

ensimmäisen

seurantavuo-

den aikana

henkilöillä,

jotka eivät

siirtyneet

työkyvyttö-

myyseläkkeel-

le. Vakioi-

mattomat ja

taustatekijöil-

lä vakioidut

osuudet.

TK-eläke = työkyvyttö-

myyseläke.
Seurantakuukaudet 1-12

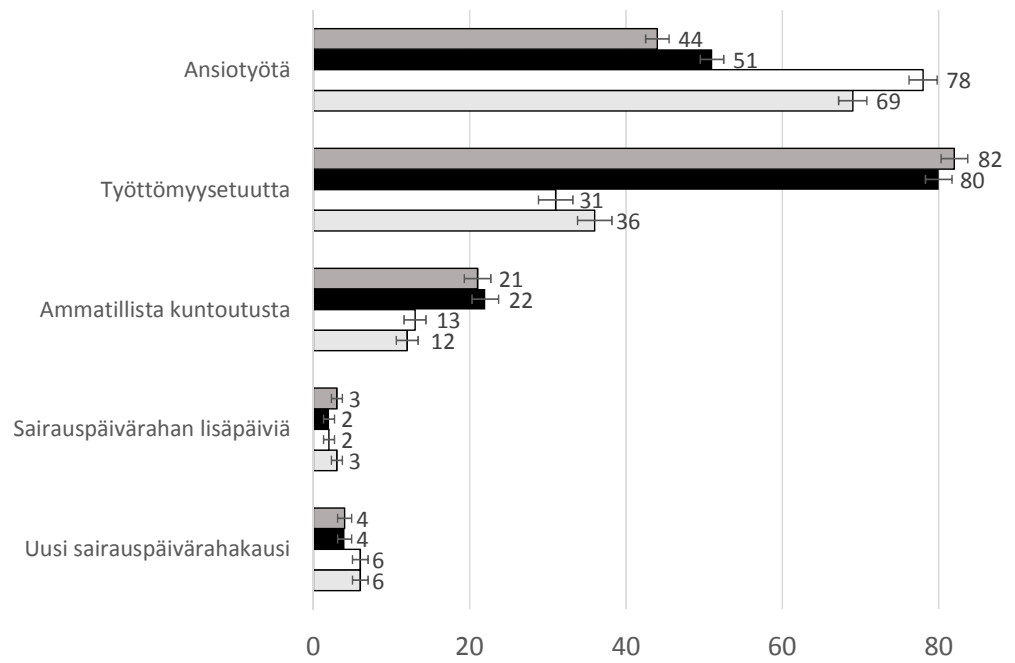

$\square$ Haki työkyvyttömyyseläkettä ja hakemus hylättiin

- Haki työkyvyttömyyseläkettä ja hakemus hylättiin: taustatekijät vakioitu

$\square$ Ei TK-eläkehakemusta

$\square$ Ei TK-eläkehakemusta: taustatekijät vakioitu
Kuvio 2.

Toimeentulon lähteet toisen seurantavuoden aikana henkilöillä, jotka eivät siirtyneet työkyvyttömyyseläkkeelle. Vakioimattomat ja taustatekijöillä vakioidut osuudet.

TK-eläke $=$ työkyvyttömyyseläke.

\section{Seurantakuukaudet 13-24}

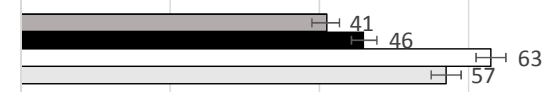

Ansiotyötä

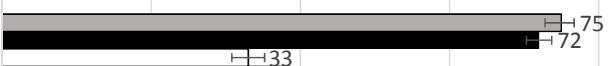

Työttömyysetuutta

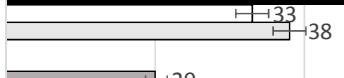

Ammatillista kuntoutusta

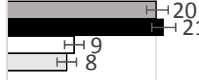

Uusi sairauspäivärahakausi

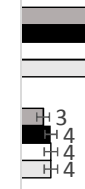

Työkyvyttömyyseläke

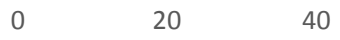

60

80

$\square$ Haki työkyvyttömyyseläkettä ja hakemus hylättiin

- Haki työkyvyttömyyseläkettä ja hakemus hylättiin: taustatekijät vakioitu

$\square$ Ei TK-eläkehakemusta

$\square$ Ei TK-eläkehakemusta: taustatekijät vakioitu 


\section{POHDINTA}

Tässä tutkimuksessa luotiin rekisteriaineiston perusteella katsaus siihen, mihin toimeentulo perustuu sairauspäivärahan enimmäisajan täyttymistä seuraavien kahden vuoden aikana. Työkyyttömyyseläkkeen hakeminen on pitkään sairastaneen henkilön kannalta perusteltu ja toistaiseksi myönnettynä etuutena taloudellisesti kannattava vaihtoehto, jos paluu ansiotyöhön tai työmarkkinoille ei onnistu. Yleisimmin tässä vaiheessa eläkelaitoksissa myös katsotaan, että henkilöllä on perusteltu oikeus työkyvyttömyyseläkkeeseen: esimerkiksi vuonna $201856 \%$ sai kansaneläkejärjestelmästä (41) ja $71 \%$ työeläkejärjestelmästä (30) hakemukseensa myöntävän päätöksen. Tulostemme mukaan yli kaksi kolmesta sairauspäivärahan enimmäisajan vuonna 2012 täyttäneestä siirtyikin seuraavan vuoden kuluessa työkyvyttömyyseläkkeelle.

\section{JOS EI TYÖKYYYTTÖMYYSELÄKKEELLE, MISTÄ TOIMEENTULO?}

Sairauspäivärahan enimmäisajan jälkeen työkyvyttömyyseläkehakemukseensa hylkäävän päätöksen saaneita koskevat tulokset vahvistavat aikaisempia tutkimustuloksia, joiden mukaan hylkäävää työkyvyttömyyseläkepäätöstä seuraa useimmiten työttömyysetuudella eläminen, jollei eläkettä myönnetä uudella hakemuksella $(27,32,38)$. Hylkäävät päätökset sinänsä olivat yleisimpiä naisilla, 30-49-vuotiailla ja henkilöillä ilman aiempaa ansiotyötä, henkilöillä jotka olivat työskennelleet yksityisellä sektorilla, sekä tuki- ja liikuntaelinten sairaudesta kärsivillä. Nämä huomiot vahvistavat aiempia tutkimustuloksia $(38,42,43)$. Uusi havainto on, että hylkäävän eläkepäätöksen jälkeen uudet sairauspäivärahakaudet ovat erittäin yleisiä vaaditun vuoden kestoisen työkykyisyysajan jälkeen - lähes joka kolmannella oli uusi sairauspäivärahajakso toisena seurantavuotena. Kun puolestaan työkykyisyysaikaa edustavan ensimmäisen seurantavuoden aikana uudet sairauspäivärahajaksot olivat harvinaisia, voidaan toisen seurantavuoden sairauspäivärahajaksojen olettaa syntyvän pääosin samoista sairaudellisista syistä kuin enimmäisajan täyttäneet jaksot. Työkyvyttömyyttä aiheuttavat sairaudet estävät todennäköisesti monella työn tekemisen riippumatta työkyvyttömyyseläkepäätöksestä.

Enimmäisajan täyttäneistä joka seitsemäs ei hakenut työkyvyttömyyseläkettä enimmäisaikaa seuraavan vuoden aikana. Tässä ryhmässä enim- mäisaikaa seuraavat toimeentulon lähteet olivat hyvin toisenlaisia kuin hylkäävän eläkepäätöksen saaneilla, ja erot hylkäävän päätöksen saaneiden ryhmään säilyivät, vaikka vakioimme ryhmien väliset erot taustatekijöissä. Eläkehakemuksen sijaan todennäköisin toimeentulon muoto oli tällä ryhmällä ansiotyö. Tämä voi selittyä osittain aiemman ansiotyön olemassaololla: ansiotyössä oleminen ennen työkyvyttömyyttä lisäsi todennäköisyyttä eläkehakemuksen puuttumiseen. Moni todennäköisesti palasikin sairauspoissaolon jälkeen olemassa olevaan työhönsä, kenties jollakin tapaa muokatulla toimenkuvalla. Toisaalta ansiotyön todennäköisyys laski selvästi toiseen seurantavuoteen, mikä kertonee siitä, että moni palaa työhön enimmäisajan jälkeen, muttei sairautensa takia kuitenkaan pysty jatkamaan entisessä työssään. Kolmannes työkyvyttömyyseläkettä hakematta jättäneistä saikin työttömyysetuutta ensimmäisen seurantavuoden aikana, ja osuus nousi hieman toisena seurantavuotena. Myös huomiomme uusien sairauspäivärahajaksojen yleisyydestä (noin joka viidennellä) toisen seurantavuoden aikana osoittaa, että pysyvä työhön paluu on haastavaa, kun pitkään jatkunut sairaus on heikentänyt työkykyä. Suhteellisen harva niistä, jotka eivät hakeneet työkyvyttömyyseläkettä, oli seuraavien vuosien aikana ollut ammatillisessa kuntoutuksessa. Kuntoutuksessa olleiden osuuksia voidaan pitää jopa huomiota herättävän alhaisina ottaen huomioon sen, että ammatillisen kuntoutuksen tiedetään monella palauttavan työkykyä ja nostavan lyhyen aikavälin seurannoissa tulevan työssäolon todennäköisyyttä (44-46).

\section{MINKÄLAINEN TAUSTA ON HENKILÖILLÄ, JOTKA EIVÄT PÄÄDY HAKEMAAN TYÖKYYYTTÖMYYSELÄKETTÄ?}

Tarkastelimme myös, miten sairauspäivärahan enimmäisajan jälkeen eläkettä hakematta jättäneet erosivat taustaltaan työkyvyttömyyseläkkeelle siirtyneistä. Ansiotyön olemassaolo työkyvyttömyyden alkaessa oli tyypillisempää eläkettä hakematta jättäneillä. Kuten yllä todettiin, ehkäisee työn olemassaolo oletettavasti eläkkeen hakemista, koska osa pystyy palaamaan entiseen työhönsä. Toisin päin ajateltuna eläke tarjoaa työttömyyttä varmemman toimeentulon, ja siksi ilman ansiotyötä olevat hakevat muita useammin eläkettä - seurauksena joko siirtyminen eläkkeelle tai hylkäävä päätös. Toisaalta asiaan vaikuttanee 
myös se, että työttömille ei ole sairauspäivärahakauteen rakennettu sairausvakuutuslain mukaisia seurantapisteitä. Ilman ajallisesti riittävän tiivistä tukijärjestelmää työkyvyttömyys pahenee herkemmin sairausjakson aikana ja voi siten myös johtaa useammin eläkkeeseen. Työttömien tiedetään hakevan (43) ja siirtyvän (47) muita useammin työkyvyttömyyseläkkeelle.

Myös ylempi toimihenkilöasema ja edellinen ansiotyö julkisella sektorilla olivat yleisempiä henkilöillä, jotka eivät hakeneet työkyvyttömyyseläkettä, kuin eläkkeelle siirtyneillä. Aiempien tutkimusten mukaan toimihenkilöasema voi lisätä työhön paluun todennäköisyyttä sairauden tai ammatillisen kuntoutuksen jälkeen $(19,21)$. Mahdollisesti ylemmillä toimihenkilöillä on työntekijäasemassa olevia useammin mahdollisuus palatessaan muokata työnkuvaa sairauden aiheuttamien rajoitusten mukaisesti. Tulos työsektorista on osin yllättävä, koska julkisen työsektorin osalta työkyvyttömyyseläkkeen kriteerit ovat yksityistä sektoria lievemmät ja siten se voisi lisätä eläkkeelle siirtymisen todennäköisyyttä. Toisaalta julkisella työsektorilla saattaa kynnys työsuhteen katkaisemiseen sairauden pitkittyessä olla yksityistä korkeampi, sallien työhön palaamisen sairauspäivärahan enimmäisajan jälkeen yksityistä sektoria yleisemmin. Lisäksi työkyvyttömyyseläkettä hakematta jättäneiden enimmäisaika oli täyttynyt eläkkeelle siirtyneitä useammin erillisistä, epäyhtenäisistä sairausjaksoista. Epäyhtenäisyys selittynee monen kohdalla ansiotyön olemassaololla. Töihin paluuta on saatettu usein kokeilla sairausjaksojen välissä.

Eläkettä hakematta jättäneille oli eläkkeelle siirtyneisiin verrattuna tyypillisempää TULE- tai muu sairaus kuin mielenterveyden häiriö. Ansiotyöhön tai aktiivisille työmarkkinoille paluu pitkiltä sairauspoissaoloilta voi olla erityisen vaikeaa mielenterveyden häiriöistä kärsivillä. Työhön paluun onnistuminen eläkkeen hakemisen sijaan on myös osin kiinni omaan pystyvyyteen liittyvistä uskomuksista, jotka voivat olla heikkoja mielenterveyden ongelmista kärsivillä (48). Tuloksemme on yhdenmukainen aiempien tutkimushavaintojen kanssa, joiden mukaan mielenterveyden häiriö voi lisätä työkyvyttömyyseläkeriskiä ja vähentää sairausjakson jälkeistä paluuta työhön $(4,13,24,25)$. Samoin psykoterapian saatavuuden vaikeudet voivat osaltaan lisätä eläkkeen hakemisen todennäköisyyttä.

\section{JATKOTUTKIMUKSEN TARVE}

Tutkimuksemme ei ole täysin kattava ajatellen seurattavia toimeentulon muotoja. Emme voineet tarkastella kaikkia toimeentulon muotoja tai sosiaaliturvan etuuslajeja, johtuen tutkimuksen jo valmiiksi laajasta asetelmasta. Työkyvyttömyyseläkkeiden kohdalla emme eritelleet työeläkkeistä täysiä ja osatyökyvyttömyyseläkkeitä toisistaan, emmekä myöskään toistaiseksi myönnettyjä ja määräaikaisia (kuntoutustuki) eläkkeitä. Jatkossa tutkimuksissa olisi otettava paremmin huo mioon paitsi nämä eläkkeen muodot, myös sairauspäivärahan aikaiset kuntoutusmuodot. Emme myöskään selvittäneet tutkittavien pääasiallista toimeentulon muotoa tai tarkentaneet seuranta-aikana vallinneiden toimeentulon muotojen välisiä siirtymiä. Toisaalta tutkimuksen tarkoitus oli paikata yleistietämyksen puutetta sairauspäivärahan enimmäisajan jälkeisistä toimeentulon lähteistä eikä kattaa kaikkia tietoja toimeentulopoluista. Tarkastelua on kuitenkin syytä tarkentaa myöhemmissä tutkimuksissa.

\section{JOHTOPÄÄTÖKSET KÄYTÄNTÖÖN}

Tutkimuksemme näyttää, että sairauspäivärahakauden enimmäismäärä täyttyy ja muuttuu työkyvyttömyyseläkkeeksi vuosittain suurella joukolla suomalaisia. Työkyvyttömyyttä ja pitkiä sairauspoissaoloja on siksi ehkäistävä ennakoivasti. Toisaalta sairastumista tai vammautumisia ei voida täysin välttää. Siten poissaolojen pitkittymisen ja sairauspäivärahan enimmäisajan jälkeisen eläköitymisen ehkäiseminen vaatii erityisesti oikeita menettelyjä sairauspäivärahajakson aikana. Tutkimustieto sairausvakuutuslain ja työterveyshuoltolain mukaisen, niin sanottujen 30-60-90-seurantapisteiden hyödyistä sairausjaksojen lyhentämiselle ja työhön paluulle on vähäistä. Työterveyslaitoksen johtamassa tutkimuksessa (49) verrattiin sairauspäivärahaprosesseja ennen ja jälkeen vuoden 2012 lakimuutoksen. Tutkimuksessa todettiin, että lakiin tuotu 30 päivän seurantapiste, joka varmistaa, että tieto poissaolon jatkumisesta tulee työterveyshuollon tietoon, lyhensi minimaalisesti työhön palaamisen keskimääräistä aikaa. Se myös lyhensi keskimäärin hieman sairauspäivärahajakson lopullista pituutta. Sen sijaan 60 päivän seurantapiste ei vaikuttanut työhön paluuseen. Kahden kuukauden kohdalla työterveyshuollon on arvioitava jäljellä olevaa työkykyä ja kuntoutustarvetta sekä tehtä- 
vä alustava työhön paluun suunnitelma mahdollisine työterveysneuvotteluineen (33). Päivärahaan sisällytettyjen seurantapisteiden järjestelmää on siten tarve kehittää edelleen.

Tämän tutkimuksen perusteella kolmannes sairauspäivärahan enimmäisajan täyttävistä on ansiotyön ulkopuolella työkyvyttömyyden alkaessa. Kuten ylempänä jo pohdimme, heidän kohdallaan suuri haaste on työterveyshuoltoa vastaavien palveluiden puuttuminen ja pitkien sairauspäivärahajaksojen aikana erityisesti 60 ja 90 päivän kohdalla tehtävien seurantojen puuttuminen. Tämä puute varmasti nostaa sekä sairauspäivärahan enimmäisajan täyttymisen että sen jälkeisen eläkehakemuksen todennäköisyyksiä. Työterveyshuollon ja niin sanotun 30-60-90-järjestelmän ulkopuolella olevien olisi saatava vastaavaa tukea, jotta he päätyisivät nykyistä harvemmin eläkkeenhakijoiksi. Seurantapisteiden puute koskee myös yrittäjiä. Vaikka he ovat sairausvakuutuksen piirissä ja mahdollisesti maksavat työterveyspalveluista, ei heitä koske työterveyshuollon lakisääteinen velvoite työkyvyn arvioon 90 päivän kohdalla. Aiemman tutkimuksen perusteella yrittäjien yksittäiset sairauspäivärahakaudet ovatkin muita ansiotyötä tekeviä pidempiä (50).

Yksi lisähaaste pitkittyneen työkyvyttömyyden estämisessä liittyy yksittäisten sairauspäivärahajaksojen pituuteen. Lääkärintodistusten ja -lausuntojen kirjoittamisen käytäntöjen tiedetään vaihtelevan sekä alueellisesti, että erikoisairaanhoidon ja perusterveydenhuollon välillä (51), mikä viittaa siihen, että taitoa kirjoittaa työkyvyn näkökulmasta oikeanpituisia sairauspoissaoloja voidaan edelleen kehittää. Samoin hoitavat lääkärit kokevat vaikeaksi arvioida työkyvyttömyyden kestoa ja kirjoittavat esimerkiksi potilaskuorman takia asiakkaan työkykyyn nähden liian pitkiä sairauslomia $(52,53)$. Pitkät yksittäiset sairausjaksot puolestaan harventavat työkyvyn seuraamista. Havainnot pitkien sairauspoissaolojen määräämisen motiiveista tuovat osaltaan esiin, miten terveys- ja lääkäripalvelujen riittämättömät resurssit vaikeuttavat työkyvyn tukemista monin tavoin.

\section{YHTEENVETO}

Tutkimuksemme osoittaa, että sairauspäivärahan enimmäismäärän täyttyminen indikoi valtaosalla vähintään työkyvyn osittaista menettämistä seuraavienkin vuosien osalta. Yli kaksi kolmesta siirtyi työkyvyttömyyseläkkeelle seuraavan vuoden aikana, ja tämä osuus kasvoi toisen seurantavuoden aikana. Varsinkin työttömyystausta nostaa eläkehakemuksen todennäköisyyttä enimmäisajan täytyttyä. Uudet alkaneet sairauspäivärahakaudet olivat varsin yleisiä toisena seurantavuotena eli vuoden työkykyisyysajan täytyttyä. Täyden työkyvyn palautumisen harvinaisuudesta kertovat myös ansiotyön suhteellinen harvinaisuus ja työttömyyden yleisyys niillä henkilöillä, jotka eivät siirtyneet työkyvyttömyyseläkkeelle.

Pitkään sairauspäivärahalla olevien tilannetta pitäisi tukea entistä tehokkaammin sairauspäivärahajaksojen aikana ja enimmäisajan lähestyessä. Työkyvyn palauttaminen ja jäljellä olevan työkyvyn hyödyntäminen työssä ovat ensisijaisen tärkeitä. On myös tärkeää, että työkyvyttömyydestä ohjaudutaan vakaimman mahdollisen toimeentulomuodon piiriin.

\section{RAHOITTAJAT:}

Hanke Rekisteritutkimus työkyvyttömyyseläkettä edeltävästä ajasta on osa Strategisen tutkimuksen neuvoston (STN) rahoittamaa TITA (Eriarvoisuuden torjuminen niukkuuden aikana) -konsortiohanketta (rahoitusnumerot 293103 ja 314250)

\section{KIRJOITTAJIEN KONTRIBUUTIOT:}

Perhoniemi suunnitteli tutkimusasetelmaa, valmisti vastuukirjoittajana käsikirjoituksen ja teki analyysit. Blomgren suunnitteli tutkimusasetelmaa, antoi vanhemman asiantuntijan apua analyyseihin ja osallistui kirjoittamiseen. Laaksonen suunnitteli tutkimusasetelmaa, antoi vanhemman asiantuntijan apua analyyseihin ja osallistui kirjoittamiseen. 
We examined sources of income after the maximum sickness allowance period of 300 days. We also examined how allowance recipients' background was associated with the probability of a disability pension application.

A $70 \%$ population sample aged $18-60$ was drawn from national registers. Disability pension was examined as the primary source of income. Other income sources were examined as prevalences, controlling for the background variables. The effect of background for the probability of a pension application was tested using chi-square tests.

During the year following the sickness allowance period, $68 \%$ transferred to disability pension, $14 \%$ didn't apply for pension and $18 \%$ had their application rejected. Especially unemployment increased the probability of a disability pension application. Those with no pension application were typically became employed during the first follow-up year (69\%). Unemployment was common among rejected pension applicants during both follow-up years $(80 \%, 72 \%)$. New sickness allowance periods were common during the second follow-up year.

For most, the maximum sickness allowance period means losing full occupational ability, irrespective of awarded disability pensions. More support is needed during disability and when approaching the maximum allowance period mark. This applies especially to the unemployed, who are without occupational health services or statutory check-ups.

Keywords: sickness allowance, maximum allowance period, disability pension, sources of income

Saapunut 13.2.2020

Hyväksytty 21.8.2020

\section{LÄHTEET}

(1) OECD. Public spending on incapacity. Luettu 12.1.2020. doi: 10.1787/f35b71ed-en.

(2) OECD. Sickness, disability and work: Breaking the barriers - A synthesis of findings across OECD countries. Paris: OECD, 2010.

(3) Alexanderson K, Kivimäki M, Ferrie J, ym. Diagnosis-specific sick leave as a long-term predictor of disability pension: a 13-year followup of the GAZEL cohort study. J Epidemiol Commun H 2012;66:155-159. doi: 10.1136/jech.2010.126789.

(4) Kivimäki M, Ferrie J, Hagberg J, ym. Diagnosisspecific sick leave as a risk marker for disability pension in a Swedish population. J Epidemiol Commun H 2007;61:915-920. doi: 10.1136/jech.2006.055426.

(5) Salonen L, Blomgren J, Laaksonen M, Niemelä M. Sickness absence as a predictor of disability retirement in different occupational classes: a register-based study of a working-age cohort in Finland in 2007-2014. BMJ Open 2018 doi: 10.1136/bmjopen-2017-020491.

(6) Allebeck P, Mastekaasa A. Swedish Council on Technology Assessment in Health Care (SBU). Chapter 5. Risk factors for sick leave - general studies. Scand J Public Health 2004;32(Suppl. 63):49-108.

(7) Blomgren J. Pitkät sairauspoissaolot työikäisillä naisilla ja miehillä. Sairauspäivärahan saajat

1996-2015. Yhteiskuntapolitiikka 2016;81:681691.

(8) Laaksonen M, Mastekaasa A, Martikainen P, Rahkonen O, Piha K, Lahelma E. Gender differences in sickness absence - the contribution of occupation and workplace. Scand J Work Environ Health 2010;36:394-403. doi: $10.2307 / 40967875$.

(9) Leinonen T, Solovieva S, Husgafvel-Pursiainen $\mathrm{K}$, ym. Julkisen ja yksityisen sektorin välinen ero sairauspoissaoloissa on säilynyt väestötasolla mutta pienentynyt sote-alalla. Duodecim2018;134:1738-1748.

(10) Löve J, Hensing G, Holmgren K, Torén K. Explaining the social gradient in sickness absence:a study of a general working population in Sweden. BMC Public Health 2013; 13:545 (9 s). doi: 10.1186/1471-2458-13-545.

(11) Pekkala J, Blomgren J, Pietiläinen O, Lahelma E, Rahkonen O. Occupational class differences in diagnostic-specific sickness absence: a registerbased study in the Finnish population, 20052014. BMC Public Health 2017;17:670 (12 s). doi: 10.1186/s12889-017-4674-0.

(12) Bruusgaard D, Smeby L, Claussen B. Education and disability pension: a stronger association than previously found. Scand J Public Health 2010;38:686-90. doi: doi: $10.1177 / 1403494810378916$. 
(13) Gjesdal S, Bratberg E. Diagnosis and duration in sickness-absence as predictors for disability pension. Results from a three-year, multi-register based and prospective study. Scand J Public Health 2003;31:246-54. doi: 10.1080/14034940210165154.

(14) Karlsson N, Carstensen J, Gjesdal S, ym. Risk factors for disability pension in a populationbased cohort of men and women on longterm sick leave in Sweden. J Public Health 2008;18:224-231. doi: 10.1093/eurpub/ckm128.

(15) Leinonen T, Martikainen P, Lahelma E. Interrelationships between education, occupational social class, and income as determinants of disability retirement. Scand J Public Health 2012;40:157-66. doi: $10.1177 / 1403494811435492$.

(16) Polvinen A, Gould R, Lahelma E, Martikainen P. Socioeconomic differences in disability retirement in Finland: the contribution of illhealth, health behaviors and working conditions. Scand J Public Health 2013;41:470-478. doi: $10.1177 / 1403494813482400$.

(17) Cancelliere C, Donovan J, Stochkendahl M, ym. Factors affecting return to work after injury or illness: best evidence synthesis of systematic reviews. Chiropr Man Therap 2016;24:32 (23 s.). DOI: 10.1186/s12998-016-0113-z. doi: 10.1186/s12998-016-0113-z.

(18) Islam T, Dahlui M, Majid H, ym. Factors associated with return to work of breast cancer survivors: a systematic review. BMC Public Health. 2014;14 Suppl 3:8 (13 s.). doi: 10.1186/1471-2458-14-S3-S8. Epub 2014. DOI: 10.1186/1471-2458-14-S3-S8.

(19) Øyeflaten I, Lie S, Ihlebæk C, ym. Prognostic factors for return to work, sickness benefits, and transitions between these states: A 4-year Follow-up After Work-Related Rehabilitation. J Occup Rehabil 2014;24: 199-212. doi: 10.1007/s10926-013-9466-5.

(20) Selander J, Marnetoft S, Asell M. Predictors for successful vocational rehabilitation for clients with back pain problems. Disabil Rehabil 2007;29:215-20. doi: $10.1080 / 09638280600756208$.

(21) Vestling M, Tufvesson B, Iwarsson S. Indicators for return to work after stroke and the importance of work for subjective well-being and life satisfaction. J Rehabil Med 2003;35:127131. doi: 10.1080/16501970310010475.

(22) Gjesdal S, Bratberg E, Maeland J. Musculoskeletal impairments in the Norwegian working population: the prognostic role of diagnoses and socioeconomic status: a prospective study of sickness absence and transition to disability pension. Spine 2009;34:1519-25. doi: 10.1097/BRS.0b013e3181a8dee3.

(23) Gjesdal S, Bratberg E, Mæland J. Gender differences in disability after sickness absence with musculoskeletal disorders: five-year prospective study of 37,942 women and 26,307 men. BMC Musculoskelet Disord 2011;12:37. doi: 10.1186/1471-2474-12-37.
(24) Pedersen J, Bjorner J, Burr H, Christensen K. Transitions between sickness absence, work, unemployment, and disability in Denmark 2004-2008. Scand J Work Environ Health 2012;36:516-526. doi: 10.5271/sjweh.3293.

(25) Pedersen P, Lund T, Lindholdt L, ym. Labor market trajectories following sickness absence due to self-reported all cause morbidity-a longitudinal study. BMC Public Health 2016;16:337-346. doi: 10.1186/s12889-016-3017-x.

(26) Galaasen A, Bruusgaard D, Claussen B. Excluded from social security: Rejections of disability pension applications in Norway 1998-2004. Scand J Public Health. 2012;40:142-149. doi: $10.1177 / 1403494811435497$.

(27) Perhoniemi R, Blomgren J, Laaksonen M. Mitä hylkäävän työkyvyttömyyseläkepäätöksen jälkeen? Työttömyys-, sairauspäivärahaja kuntoutusrahaetuudet sekä uudet eläkepäätökset neljän vuoden seurannassa. Yhteiskuntapolitiikka 2018;83:117-131.

(28) von Wachter T, Song J, Manchester J. Trends in employment and earnings of allowed and rejected applicants to the social security disability insurance program. Am Econ Rev 2011;101:3308-3329. doi: 10.1257/aer.101.7.3308.

(29) Blomgren J. Mielenterveyden häiriöistä johtuvien sairauspoissaolojen kasvu jatkuu jyrkkänä. Tutkimusblogi, Kelan tutkimus 29.1.2020. Luettu 12.2.2020.https://tutkimusblogi.kela.fi/ arkisto/5168

(30) Eläketurvakeskus (ETK). Tilastotietokanta. Luettu 1.1.2020. https://www.etk.fi/tutkimustilastot-ennusteet/tilastot/tilastotietokanta/

(31) Määttä A. Työkyvytön vai työtön? Työkyvyttömyydestä aiheutuva sosiaaliturvan väliinputoaminen elämänkaaren eri vaiheissa. Kuntoutus 2011;34:18-28.

(32) Perhoniemi R, Blomgren J, Laaksonen M. Sources of income following a rejected disability pension application: a sequence analysis study. Disability and Rehabilitation 2019a; sähköinen versio julkaistu. doi: 10.1080/09638288.2018.1555619.

(33) Sairausvakuutuslaki, SVL 1224/2004

(34) Kela. Kelasto-tilastopalvelu. Luettu 3.1.2020. http://kelasto.kela.fi/approot/simile/kelasto.html

(35) Kuuva N. Takaisin työhön vai työkyvyttömyyseläkkeelle. Työkykyä palauttavat prosessit. Eläketurvakeskuksen Keskustelualoitteita 5/2011. Helsinki: ETK; 2011.

(36) Työntekijän eläkelaki, 395/2006

(37) Engström P, Hägglund P, Johansson P. Early Interventions and Disability Insurance: Experience from a Field Experiment. Econ J 2017;127:363-392. doi: 10.1111/ecoj.12310.

(38) Laaksonen M, Gould R, Liukko J. Labor market position after a rejection of a disability pension application: A register-based cohort study. 
Disabil Rehabil 2017;40:3022-3029. doi: 10.1080/09638288.2017.1367039.

(39) Tilastokeskus. Sosioekonomisen aseman luokitus. Helsinki: Tilastokeskus, Käsikirjoja 17, 1989. Luettu 10.5.2020. https://www.stat.fi/meta/ luokitukset/sosioekon_asema/001-1989/kasikirja. pdf

(40) Julkisten alojen eläkelaki 81/2016, 33 \$

(41) Kela. Kelan julkaisemattomat tilastot.

(42) Gould R, Nyman H. Työkyvyttömyyseläkepäätökset 2000-2011. Eläketurvakeskuksen keskustelualoitteita 3/2012. Helsinki: Eläketurvakeskus; 2012.

(43) Perhoniemi R, Blomgren J, Laaksonen M. Determinants of disability pension applications and awarded disability pensions in Finland, 2009 and 2014. Scand J Public Health 2019b; sähköinen versio julkaistu. doi: 10.1177/1403494819843778.

(44) Leinonen T, Viikari-Juntura E, HusgafvelPursiainen K, ym. The effectiveness of vocational rehabilitation on work participation: a propensity score matched analysis using nationwide register data. Scand J Work Environ Health 2019; sähköinen versio julkaistu. doi: 10.5271/sjweh.3823.

(45) Reiterä T, Miettinen S, Rättö H, ym. Kelan kuntoutuksen hyödyn arviointi 2017. Kuntoutusta kehittämässä 10 / 2019. Helsinki: Kela; 2019.

(46) Tuomala J. Vaikuttaako kuntoutus työssä jatkamiseen? Kirjassa: Gould R, Härkäpää K, Järvikoski A, toim. Toimiiko työeläkekuntoutus? Eläketurvakeskuksen tutkimus 1/2012. Helsinki: ETK; 2012, 163-192.

(47) Laaksonen M, Nyman H. Työttömien ja ikääntyneiden siirtyminen työkyvyttömyyseläkkeelle on vähentynyt selvästi. Lääkärilehti 2019;33:1745-1748.

(48) Huijs J, Koppes L, Taris T, Blonk R. Differences in predictors of return to work among longterm sick-listed employees with different selfreported reasons for sick leave. J Occup Rehabil 2012;22:301-11.

doi: 10.1007/s10926-011-9351-z.
(49) Viikari-Juntura E, Leinonen T, Virta L, ym. Utilisation of nationwide register data to assess the effectiveness of changes in sickness insurance legislation on work participation and analyse sickness absence and disability retirement trends in Finland. Tijdschr voor Bedrijfs 2018;26:334339. doi: 10.1007/s12498-018-0235-4.

(50) Blomgren J, Jäppinen S. Sairauspäiväraha maksetaan useimmin työntekijäammateissa toimiville. Sosiaalivakuutus 2016;3:32-32.

(51) Kankaanpää, A, Franck, J. \& Tuominen, R 2012. Variations in primary care physicians' sick leave prescribing practices. Eur JPublic Health 2012;22:92-96. doi: 10.1093/eurpub/ckr031.

(52) Hinkka K, Niemelä M, Autti-Rämö I, ym. Physicians' experiences with sickness absence certification in Finland. Scand J Pub Health. sähköinen versio julkaistu. doi: 10.1177/1403494818758817.

(53) Löfgren A, Hagberg J, Alexanderson K. Frequency and nature of problems associated with sickness certification tasks: A cross-sectional questionnaire study of 5455 physicians. Scand J Prim Health 2007;25:178-185. doi: 10.1080/02813430701430854.

\section{Riku Perhoniemi}

Psykologian maisteri PsM, tutkija

Kela

Tutkimusyksikkö

Jenni Blomgren

Valtiotieteiden tohtori VTT, dosentti, tutkimuspäällikkö

Kela

Tutkimusyksikkö

Mikko LaAksonen

Filosofian tohtori FT, dosentti, erikoistutkija

Eläketurvakeskus

Tutkimusosasto 